\title{
Hutchinson-Gilford progeria syndrome: a rare premature ageing syndrome
}

\section{Zespół progerii Hutchinsona-Gilforda - rzadki zespół przedwczesnego starzenia organizmu}

Iti Varshney, Mohammad Adil, Syed Suhail Amin, Mohd Mohtashim, Annu Priya, Mahtab Alam

Department of Dermatology, Jawaharlal Nehru Medical College, Aligarh Muslim University, Aligarh, India

Dermatol Rev/Przegl Dermatol 2020, 107, 179-183

DOI: https://doi.org/|0.5। |4/dr.2020.9636|

CORRESPONDING AUTHOR/ ADRES DO KORESPONDENCJI:

Mohammad Adil

Department of Dermatology

Jawaharlal Nehru Medical College

Aligarh Muslim University

Aligarh, India

Phone: +918171169131

E-mail: dr.mohd.adil@gmail.com

\begin{abstract}
Hutchinson-Gilford progeria syndrome is an extremely rare genetic disorder characterized by premature ageing involving the skin, bones, heart, and blood vessels. The incidence is 1 in several million births. It occurs sporadically and is probably an autosomal dominant syndrome. The diagnosis is essentially clinical and the manifestations become more evident from the first year of life. We report a case of a seven-monthold boy with clinical manifestations characteristic of this syndrome. He had a characteristic "plucked-bird" appearance, prominent eyes and scalp veins, senile look, loss of scalp hair, stunted growth and mottled pigmentation with sclerodermatous changes over the trunk and lower limbs. This interesting case is reported for its rarity.
\end{abstract}

\section{STRESZCZENIE}

Zespół progerii Hutchinsona-Gilforda to niezwykle rzadki, uwarunkowany genetycznie zespól, który charakteryzuje się przedwczesnym procesem starzenia skóry, kości, serca i naczyń krwionośnych. Częstość występowania wynosi 1 na kilka milionów urodzeń. Zespół występuje sporadycznie i prawdopodobnie jest dziedziczony w sposób autosomalny dominujący. Rozpoznanie opiera się przede wszystkim na ocenie klinicznej, a objawy stają się bardziej widoczne od pierwszego roku życia. Poniższy artykuł przedstawia przypadek siedmiomiesięcznego chłopca z klinicznymi objawami charakterystycznymi dla tego zespołu. Chłopiec miał znamienny wygląd "oskubanego ptaka”, tj. nieprawidłowo osadzone oczy, wyraźnie widoczne żyły na skórze głowy, starczy wygląd, nie miał włosów na głowie, przebieg wzrostu był opóźniony, obecne były plamy pigmentacyjne i stwardnienie skóry na tułowiu i kończynach dolnych. Ten interesujący przypadek został opisany ze względu na swoją rzadkość.

Key words: premature ageing syndrome, progeria, ageing.

Słowa kluczowe: zespół przedwczesnego starzenia, progeria, starzenie. 


\section{INTRODUCTION}

Hutchison-Gilford progeria syndrome (HGPS) is an extremely rare genetic disorder that primarily affects the skin, bones and the cardiovascular system. It is characterized by low birth weight, short stature, loss of subcutaneous fat, sclerodermoid changes, prominent superficial veins, peculiar facies and extremities that resemble those of an old person. $\mathrm{Pa}-$ tients tend to die early due to myocardial infarction or cerebrovascular accident as a result of atheroma formation [1].

Progeria has fascinated clinicians for a century because the disease has been seen as a window into the process of ageing. Less than 150 cases have been reported to date with most case reports from the Western countries [2].

\section{OBJECTIVE}

This case report is intended to document another case of HGPS with classical features in a 7-month-old boy.

\section{CASE REPORT}

A 7-month-old boy presented to us with loss of scalp hair since 3 months of age along with stunted growth as a major complaint. The mother also complained that the child slept with his eyes open. She noticed skin lesions over the abdomen since 4 months of age. There was no history of convulsion or consanguineous marriage in parents. No other family members were affected or had similar complaints. The patient was a full-term caesarean delivery and cried immediately after birth.

On examination, he was short with weight of $6.4 \mathrm{~kg}\left(<3^{\text {rd }}\right.$ centile $)$, height of $66 \mathrm{~cm}\left(<3^{\text {rd }}\right.$ centile $)$ and head circumference of $49 \mathrm{~cm}(>2 \mathrm{SD}$ ) suggesting macrocephaly. He had distinctive facies with prominent eyes, diffuse hair loss, prominent scalp and facial veins, micrognathia and beaked nose (fig. 1). Hair of eyebrows and eyelashes were normal. Mottled pigmentation and sclerodermatous changes were present over the trunk and bilateral thighs (fig. 2). Reduced subcutaneous fat on the face and muscle atrophy over limbs were other important features. Mild myopia was present and the rest of the ophthalmic examination was within normal limits. Genitalia were normal with descended testes. The rest of the physical examination was normal.

Routine investigations including blood counts, liver and renal function tests, urine and stool examination and lipid profile was within normal range. Thyroid and growth hormones were normal. ECG and ultrasonography of the abdomen showed no

\section{WPROWADZENIE}

Zespół progerii Hutchinsona-Gilforda (Hutchinson-Gilford progeria syndrome - HGPS) to niezwykle rzadkie zaburzenie genetyczne, które wpływa głównie na skórę, kości i układ sercowo-naczyniowy. Charakteryzuje się małą masą urodzeniową, niskim wzrostem, utratą podskórnej tkanki tłuszczowej, zmianami twardzinopodobnymi, wyraźnie widocznymi powierzchniowymi żyłami oraz osobliwym wyglądem twarzy i kończyn, które przypominają osobę starszą. Pacjenci mają tendencję do wczesnych zgonów z powodu zawału mięśnia sercowego lub udaru mózgu, które są wynikiem tworzenia się blaszki miażdżycowej [1].

Progeria fascynuje klinicystów od wieku, ponieważ uważa się, że choroba daje wgląd w proces starzenia. Do tej pory stwierdzono mniej niż 150 przypadków, a większość doniesień pochodzi z krajów zachodnich [2].

\section{CEL PRACY}

Celem artykułu jest przedstawienie przypadku HGPS z klasycznymi cechami charakterystycznymi, który wystąpił u 7-miesięcznego chłopca.

\section{OPIS PRZYPADKU}

Siedmiomiesięczny chłopiec został przyjęty głównie z powodu utraty włosów na skórze głowy od 3. miesiąca życia i opóźnionego wzrostu. Matka chłopca zgłosiła również, że dziecko sypia z otwartymi oczami. Zauważyła zmiany skórne na brzuchu występujące od 4 . miesiąca życia. W wywiadzie brak drgawek, a rodzice dziecka nie są spokrewnieni. Nikt z członków rodziny nie miał podobnych dolegliwości. Dziecko urodziło się o czasie przez cesarskie cięcie i płakało zaraz po urodzeniu.

W trakcie badania stwierdzono, że pacjent ważył $6,4 \mathrm{~kg}(<3$. centyla), miał $66 \mathrm{~cm}$ wzrostu $(<3$. centyla), a jego obwód głowy wynosił $49 \mathrm{~cm}(>2 \mathrm{SD})$, co sugerowało makrocefalię. Chłopiec miał charakterystyczny wygląd twarzy z dużymi, wydatnymi oczami, występowało u niego łysienie rozlane, żyły na skórze głowy i twarzy były wyraźnie widoczne, obecny był niedorozwój żuchwy i „ptasi” koniec nosa (ryc. 1). Brwi i rzęsy były w normie. Stwierdzono przebarwienia i stwardnienia na tułowiu i obustronnie na udach (ryc. 2). Inne charakterystyczne cechy to niedobór podskórnej tkanki tłuszczowej na twarzy i zanik mięśni kończyn. U pacjenta wykazano łagodną krótkowzroczność, pozostałe wyniki badania okulistycznego były w normie. Zewnętrzne narządy płciowe były w normie, jądra zstąpione. Pozostałe wyniki badania fizykalnego były w normie. 


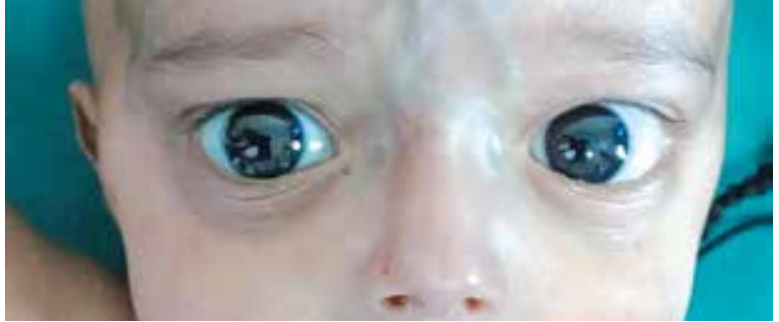

Figure I. Characteristic facies with prominent eyes

Rycina I. Charakterystyczny wygląd twarzy z dużymi, wydatnymi oczami

abnormality. Radiographs of the skull, chest and extremities were normal. The parents did not agree to the skin biopsy. The child was diagnosed with HGPS and parents were counselled regarding the prognosis and need for regular follow-up. Testing for LMNA mutation was not done due to financial constraints.

\section{DISCUSSION}

The word "progeria" comes from the Greek word progeros meaning prematurely old (pro means "before" and geras means "old age"). Hutchinson described the first patient in 1886 as a case of 'congenital absence of hair and its appendages', while the term progeria was introduced by Hastings Gilford.

The exact aetiology of progeria is not known, but it is believed to be an autosomal dominant disorder that occurs due to de novo point mutations in lamin A (LMNA) gene, located on chromosome 1q22. The LMNA gene encodes for prelamin A, which is cleaved to form lamin A by removal of the farnesyl group and attaches to the nuclear membrane. Patients with progeria have a GGC to GGT mutation in the LMNA gene, leading to generation of a truncated splicing mutant of lamin A called progerin. It leads to failure in cleaving this farnesyl group, leading to permanent attachment of this protein to the membrane. This leads to impaired nuclear morphology, integrity, defective DNA repair and telomere instability, leading to premature cell senescence and death [3,4].

Children appear normal at birth. The earliest feature is growth deficiency in the first year of life. These patients exhibit characteristic facies, alopecia in the first 2 years of life, short stature, sclerodermatous change, reduced subcutaneous fat on the face and limbs, "sculptured nasal tip", easy bruising, progressive mottled hyperpigmentation, prominent scalp veins, and joint deformities [5]. The histopathologic changes in the skin include atrophy of epidermis and dermis. There is progressive hyalinization of dermal collagen and loss of subcutaneous fat [6]. Macrocephaly, decreased sweating, nail dystrophy, onych-



Figure 2. Sclerodermatous skin of the trunk

Rycina 2. Stwardnienia na skórze tułowia

Wyniki badań podstawowych obejmujących morfologię krwi, próby czynnościowe wątroby i nerek, moczu i kału, a także profil lipidowy były w normie. Stężenia hormonów tarczycy i hormonu wzrostu były w normie. EKG i USG jamy brzusznej nie wykazały nieprawidłowości. Badanie RTG czaszki, klatki piersiowej i kończyn było w normie. Rodzice nie wyrazili zgody na pobranie wycinka skóry. U dziecka rozpoznano HGPS, a rodzice zostali poinformowano o prognozie i potrzebie regularnych kontroli. Badanie w kierunku mutacji genu LMNA nie zostało przeprowadzone z powodów finansowych.

\section{OMÓWIENIE}

Słowo „progeria” pochodzi od greckiego słowa progeros, które oznacza przedwczesną starość (pro znaczy "przed”, a geras „wiek starczy”). Pierwszy pacjent został opisany przez Hutchinsona w 1886 r. jako przypadek „,wrodzonego braku owłosienia i przydatków skóry”, a określenie „progeria” zostało wprowadzone przez Hastingsa Gilforda.

Dokładna etiologia progerii jest nieznana, ale uważa się, że jest to zaburzenie dziedziczone autosomalnie dominująco, które jest spowodowane mutacją punktową de novo w genie LMNA kodującym laminę A położonym na chromosomie 1q22. Gen LMNA 
ogryphosis, koilonychia, hypoplastic nipples, keloids, delayed and abnormal dentition can also be seen [7].

Cutaneous manifestations are followed by skeletal and cardiovascular systems. Cardiovascular involvement occurs in the form of extensive atheromas, myocardial fibrosis, lipofuscin deposition and strokes. Skeletal abnormalities include osteolysis, osteoporosis, necrosis, dislocation, fracture, dystrophic clavicles, coxa valga, 'horse-riding' stance, thinning of cranial bones, delayed closure of cranial sutures and anterior fontanelle. Vascular sclerosis with multiple ischemic infarctions, cerebral atrophy, and vascular myelopathy is seen in the central nervous system but intelligence is normal [7]. It is interesting to note that although senile degeneration occurs in HGPS, many features of ageing like presbycusis, presbyopia, cataract, arcus senilis and osteoarthritis are not seen [8]. Differential diagnosis includes pangeria, Rothmund-Thomson syndrome and Cockayne syndrome.

Patients should have 6-12-monthly growth, cardiovascular, neurological, musculoskeletal, dental, ear and eye assessments. Lipids, electrocardiogram, echocardiogram, carotid duplex scanning, hip X-rays and bone densitometry scans should also form a part of annual care. Protection from trauma can prevent bone fractures. Dietary control and sometimes medical treatment in the form of low dose aspirin is recommended as prophylaxis to prevent atherosclerotic changes. The average life expectancy is 13 years, with an age range of 7-27 years.

Recent research has highlighted some potential therapeutic agents to reverse the underlying molecular defect in progeria, specifically by reducing the farnesylation of progerin which results in its nuclear accumulation [9]. Drugs of interest include pravastatin, lonafarnib and zolendronate, as well as rapamycin, which has been shown to reverse the cellular phenotypic deficit in vitro and to improve survival in these patients.

\section{CONCLUSIONS}

Hutchinson Gilford progeria syndrome is a rare premature ageing disorder characterised by growth retardation and features of ageing such as loss of subcutaneous fat, atheroma formation leading to myocardial infarction and stroke. Classical cutaneous manifestations of progeria are described in this case report.

\section{CONFLICT OF INTEREST}

The authors declare no conflict of interest. koduje prelaminę A, która następnie tworzy laminę A poprzez usunięcie grupy farnezylowej i przyłączenie do błony jądrowej. Pacjenci z progerią mają mutację GGC do GGT w genie LMNA, co prowadzi do powstania skróconej splicingowanej zmutowanej laminy A - progeryny. Powoduje to niepowodzenia w podziale tej grupy farnezylowej, co z kolei prowadzi do trwałego przyłączenia tego białka do błony. Dochodzi do upośledzenia morfologii jąder, ich integralności, upośledzonej naprawy DNA i niestabilności telomerów, co z kolei prowadzi do przedwczesnego starzenia i śmierci komórek [3,4].

Dzieci po urodzeniu wyglądają normalnie. Najwcześniej pojawiającą się cechą charakterystyczną jest niedobór wzrostu w pierwszym roku życia. Pacjenci mają charakterystyczne twarze, łysienie pojawia się w pierwszych 2 latach życia, wzrost jest niski, obecne są zmiany twardzinopodobne, niedobór podskórnej tkanki tłuszczowej w obrębie twarzy i kończyn, „rzeźbiony” koniec nosa, skłonność do siniaczenia, występują postępujące plamy pigmentacyjne i deformacje stawów, a żyły na skórze głowy są wyraźnie widoczne [5]. Zmiany histopatologiczne skóry obejmują zanik naskórka i skóry właściwej. Postępuje hialinizacja kolagenu w skórze i utrata podskórnej tkanki tłuszczowej [6]. Ponadto można zaobserwować makrocefalię, zmniejszoną potliwość, dystrofię paznokci, onychogryfozę, koilonychię, niedorozwinięte sutki, bliznowce, a także opóźniony rozwój uzębienia lub nieprawidłowe uzębienie [7].

Po objawach skórnych pojawiają się symptomy ze strony układu kostnego i sercowo-naczyniowego. Zajęcie układu sercowo-naczyniowego manifestuje się rozległymi blaszkami miażdżycowymi, zwłóknieniem mięśnia sercowego, złogami lipofuscyny i udarów. Nieprawidłowości szkieletowe obejmują osteolizę, osteoporozę, martwicę, zwichnięcia, złamania, dystrofię obojczyków, koślawe biodra, chód na szerokiej podstawie, ścieńczenie kości czaszki, opóźnione zamknięcie szwów czaszkowych i ciemiączka. Stwardnienie naczyń z licznymi zawałami niedokrwiennymi, zanik mózgu i mielopatia naczyniowa są widocznymi objawami ze strony ośrodkowego układu nerwowego, ale rozwój intelektualny pacjenta jest prawidłowy. Interesujący jest fakt, że mimo że zmiany starzeniowe występuje w HGPS, to pacjenci nie mają wielu cech starzenia się, takich jak starcze przytępienie słuchu, starcze przytępienie wzroku, zaćma, obwódka starcza, choroby zwyrodnieniowe stawów [8]. Diagnostyka różnicowa obejmuje zespół Wernera, zespół Rothmunda-Thomsona i zespół Cockayne'a.

Co 6-12 miesięcy u pacjentów powinno się sprawdzać wzrost, przeprowadzać badania układu sercowo-naczyniowego, mięśniowo-szkieletowego, neurologiczne, stomatologiczne, a także okulistyczne 
i laryngologiczne. Coroczna kontrola powinna obejmować profil lipidowy, EKG, echokardiogram, obrazowanie tętnic szyjnych z badaniem przepływu, badanie RTG bioder i pomiar gęstości kości. Ochrona przed urazami może zapobiec złamaniom kości. Stosowanie diety, a niekiedy leczenie małymi dawkami kwasu acetylosalicylowego są zalecane jako profilaktyka zmian miażdżycowych. Średnia oczekiwana długość życia wynosi 13 lat (7-27 lat).

Ostatnie badania zwróciły uwagę na środki terapeutyczne, które mogą odwrócić zasadnicze wady cząsteczkowe w progerii, zwłaszcza poprzez redukcję farnezylacji progeryny prowadzącej do jej gromadzenia się w jądrach [9]. Leki brane pod uwagę to prawastatyna, lonafarnib, kwas zoledronowy i rapamycyna, w przypadku której udowodniono, że odwraca komórkowy deficyt fenotypowy in vitro i zwiększa przeżywalność pacjentów.

\section{WNIOSKI}

Zespół progerii Hutchinsona-Gilforda to rzadkie zaburzenie polegające na przedwczesnym starzeniu, które charakteryzuje się upośledzeniem wzrostu, a także cechami, takimi jak utrata podskórnej tkanki tłuszczowej i tworzenie się blaszek miażdżycowych, co prowadzi do zawału mięśnia sercowego i udaru. W artykule zostały opisane klasyczne objawy skórne progerii.

\section{KONFLIKT INTERESÓW}

References

Autorzy nie zgłaszają konfliktu interesów.

\section{Piśmiennictwo}

1. Hu Y., Xu Z.G., Xu Z., Ma L.: Hutchinson Gilford progeria syndrome caused by LMNA mutation: a case report. Pediatr Dermatol 2015, 32, 271-275.

2. Bhukya A.S., Reddy B.S.N.: Hutchinson-Gilford progeria syndrome. Indian Dermatol Online J 2015, 6, 438-440.

3. Liu G.H., Barkho B.Z., Ruiz S., Diep D., Qu J., Yang S.L., et al.: Recapitulation of premature ageing with iPSCs from Hutchinson Gilford progeria syndrome. Nature 2011, 472, 221-225.

4. Lesiak A., Bednarski I., Rogowsky-Tylman M., Sobjanek M., Woźniacka A., Danilewicz M., et al.: One week of exposure to sunlight induces progerin expression in human skin. Adv Dermatol Allergol 2017, 34, 629-631.

5. Sowmiya R., Prabhavathy D., Jaykumar S.: Progeria in siblings: a rare case report. Ind J Dermatol 2011, 56, 581-582.

6. Kashyap S., Shanker V., Sharma N.: Hutchinson-Gilford progeria syndrome: a rare case report. Indian Dermatol Online J 2014, 5, 478-481.

7. Merideth M.A., Gordon L.B., Clauss S., Sachdev V., Smith A.C., Perry M.B., et al.: Phenotype and course of Hutchinson-Gilford progeria syndrome. N Engl J Med 2008, 358, 592-604.

8. Agarwal U.S., Sitaraman S., Mehta S., Panse G.: Hutchinson-Gilford progeria syndrome. Indian J Dermatol Venereol Leprol $2010,76,591$.

9. Cao K., Graziotto J.J., Blair C.D., Mazzulli J.R., Erdos M.R., Krainc D., et al.: Rapamycin reverses cellular phenotypes and enhances mutant protein clearance in Hutchinson-Gilford progeria syndrome cells. Sci Transl Med 2011, 3, 89-58.

Accepted: 15.12 .2018

Received: 15.03 .2020

Otrzymano: $15.12 .2018 \mathrm{r}$.

Zaakceptowano: 15.03.2020 r.

How to cite this article

Varshney I., Adil M., Amin S.S., Mohtashim M., Priya A., Alam M.: Hutchinson-Gilford progeria syndrome: a rare premature ageing syndrome. Dermatol Rev/Przegl Dermatol 2020, 107, 179-183. DOI: https://doi.org/10.5114/dr.2020.96361. 